\title{
MINERALOGY OF INGILITE
}

Romashkin A.I., Kukhtina L. M.

Far Eastern Regional Information Computing Centre, Far Eastern Institute for Mineral Resources. Ministry of Natural Resources of the Russian Federation, 31, Gerasimov St., Khabarovsk 680021, Russia

The term ingilite, ingilitic rock has been introduced by F.V.Kaminsky (1969) for defining rocks with intermediate composition from kimberlites to alkaline picrites and alkaline basalts. A petrotypical area of their development is the volcanic pipe, vein and dike field with the same name located in the south-eastern margin of the Siberian platform. Ingilites formed during Late Proterozoic rifting stage in association with alkaline-ultramafic massif of central type with carbonatite (Romashkin, 1994).

Ingilitic bodies are composed of massive ingilites and ingilitic breccias, autolithic ones included. Massive ingilites and breccial cement have porphyritic structures. Phenocrysts are represented by olivine, clinopyroxene, phlogopite and picroilmenite. The rock groundmass which has microlithic structure is composed of carbonate, serpentine, phlogopite, clinopyroxene, olivine, perovskite, chrome-spinellid, and magnetite. In individual grains there have been identified orthopyroxene, amphibole, garnet, zircon, apatite, rutile, sphene, anatase, scapolite, corundum, and also obviously epigenetic - siderite, magnesite, barite, chlorite, gematite, fluorite, pyrite, chalcopyrite, azurite, malachite, leucoxene, limonite.

Olivine from phenocrysts is represented by two morphological types: big (up to $7 \mathrm{~mm}$ ) oval grains and phenocrysts of prismatic crystal habit up to $3 \mathrm{~mm}$ in size. The olivine iron content ranges from 6 to $17 \%$. An insufficient $\mathrm{CaO}$ admixture has been determined in its composition; chromium has not been found (Table).

Table. Average Chemical Composition (weight \%) of minerals of ingilites

\begin{tabular}{|l|c|c|c|c|c|c|c|c|c|c|c|}
\hline Mineral & $\mathrm{n}$ & $\mathrm{SiO}_{2}$ & $\mathrm{TiO}_{2}$ & $\mathrm{Al}_{2} \mathrm{O}_{3}$ & $\mathrm{Cr}_{2} \mathrm{O}_{3}$ & $\mathrm{FeO}^{*}$ & $\mathrm{MnO}$ & $\mathrm{MgO}$ & $\mathrm{CaO}$ & $\mathrm{Na}_{2} \mathrm{O}$ & $\mathrm{Total}$ \\
\hline Olivine & 39 & 40.80 & $\mathrm{ud}$ & $\mathrm{na}$ & $\mathrm{ud}$ & 10.10 & 0.18 & 48.66 & 0.06 & $\mathrm{na}$ & 99.80 \\
\hline Clinopyroxene 1 & 22 & 54.39 & 0.20 & 1.01 & 0.70 & 2.92 & 0.07 & 17.06 & 22.07 & 0.47 & 98.89 \\
\hline Clinopyroxene 2 & 20 & 53.31 & 0.48 & 1.50 & 0.04 & 6.78 & 0.24 & 15.08 & 20.93 & 0.87 & 99.23 \\
\hline Ilmenite 1 & 6 & $\mathrm{na}$ & 49.14 & 0.34 & 1.56 & 38.62 & 0.28 & 8.98 & $\mathrm{na}$ & $\mathrm{na}$ & 98.92 \\
\hline Ilmenite 2 & 21 & $\mathrm{na}$ & 47.18 & 0.32 & 0.27 & 44.88 & 0.35 & 5.71 & $\mathrm{na}$ & $\mathrm{na}$ & 98.71 \\
\hline Crome-spinel. 1 & 12 & $\mathrm{na}$ & 0.74 & 6.70 & 50.40 & 31.22 & 0.48 & 9.07 & $\mathrm{na}$ & $\mathrm{na}$ & 98.61 \\
\hline Crome-spinel. 2 & 8 & $\mathrm{na}$ & 11.34 & 3.20 & 28.50 & 46.51 & 0.33 & 8.97 & $\mathrm{na}$ & $\mathrm{na}$ & 98.85 \\
\hline Garnet 1 & 19 & 39.54 & 0.06 & 21.76 & 0.03 & 22.96 & 0.53 & 9.10 & 5.84 & $\mathrm{na}$ & 99.82 \\
\hline Garnet 2 & 9 & 37.66 & 0.07 & 20.87 & 0.04 & 28.79 & 3.35 & 3.37 & 5.08 & $\mathrm{na}$ & 99.23 \\
\hline Garnet 3 & 4 & 37.80 & 0.01 & 21.44 & 0.01 & 34.96 & 1.21 & 4.00 & 0.96 & $\mathrm{na}$ & 100.39 \\
\hline
\end{tabular}

Note: * all iron is in the form of FeO; ud - undiscovered; na - not analysed.

Clinopyroxene from phenocrysts forms two morphological types. The first type - angular, rounded, frequently corroded green-colored with an emerald tint grains up to $4 \mathrm{~mm}$ in size. The second type - green, dark green phenocrysts of short-prismatic shape up to $1 \mathrm{~mm}$ in size along a long axis. By 
chemical composition clinopyroxenes are subdivided into two groups (Table). The pyroxenes of the first group (the first morphological type) - chrome-diopsides and chrome-bearing clinopyroxenes are characterized by the minimum $\mathrm{FeO}$ contents and a small $\mathrm{TiO}_{2}$ admixture. According to $\mathrm{Al}_{2} \mathrm{O}_{3}$ and $\mathrm{Na}_{2} \mathrm{O}$ ratio some of their representatives correspond to chrome-diopsides of kimberlites. The clinopyroxenes of the second group (the first and the second morphological types) are depleted in chromium, enriched in iron and titanium.

Phlogopite from phenocrysts is represented by elongated plates with rounded margins from 0.7 up to $6 \mathrm{~mm}$ in size. The mineral pleochroites from pale brown, straw-yellow by Np up to dark-brown by $\mathrm{Ng}$, which indirectly indicates $\mathrm{TiO}_{2}$ enrichment .

Picroilmenite is a typical mineral for ingilites. Its grains range in size from 0.5 to $5 \mathrm{~mm}$; nodules up to $4 \mathrm{~cm}$ in diameter are rarely observed; grains are irregularly shaped as rounded-oval ones with rugged knobby surfaces. Picroilmenite generally has monocrystal structure and rarely aggregate one. By composition paramagnetic ilmenites are subdivided into two groups (Table, Fig.1). The first group is enriched in $\mathrm{MgO}$ and $\mathrm{Cr}_{2} \mathrm{O}_{3}$ along with a rather narrow compositional range (mol.\%): $\mathrm{MgTiO}_{3}$ (30-36), $\mathrm{FeTiO}_{3}(55-58), \mathrm{Fe}_{2} \mathrm{O}_{3}$ (8-13) corresponding to picroilmenites from kimberlites. The second group which includes ferrimagnetic ilmenites as well is depleted in $\mathrm{MgO}$ and $\mathrm{Cr}_{2} \mathrm{O}_{3}$ and wider compositional variations. They differ from kimberlitic picroilmenites by decreased contents of $\mathrm{MgO}$ and increased contents of crichtonite minal.

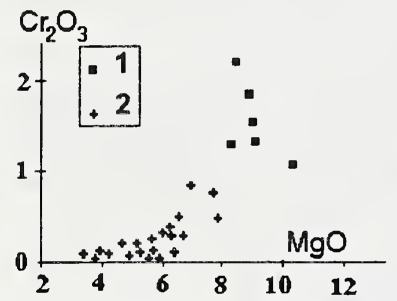

Fig. 1. Picroilmenites of ingilites on $\mathrm{MgO}-\mathrm{Cr}_{2} \mathrm{O}_{3}$ diagram 1 - first group; 2 - second group.

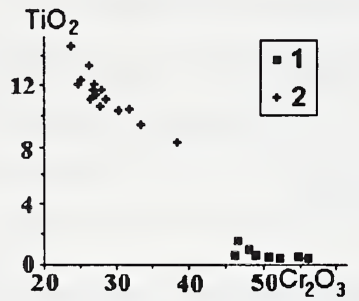

Fig. 2. Chrome-spinellids of ingilites on $\mathrm{Cr}_{2} \mathrm{O}_{3}-\mathrm{TiO}_{2}$ diagram

1- first group; 2 - second group.

Chrome-spinellids form black-colored crystals from 0.15 to $1 \mathrm{~mm}$ in size, of three morphological types (according to their abundance): 1) plane-faced, sharp-edged octahedrons with dull rugged faces; 2) octahedrons with even smooth mirror-lustrous faces and partially rounded edges and apexes; 3) distorted octahedrons or grains of rounded to irregular shapes with rugged surfaces and dull luster. According to the composition two groups of chrome-spinellids can be distinguished (Table, Fig.2) undependent on their morphology. Chrome-spinellids of the first group correspond to chrome-picotite. They are enriched in $\mathrm{Cr}_{2} \mathrm{O}_{3}, \mathrm{Al}_{2} \mathrm{O}_{3}$, depleted in $\mathrm{TiO}_{2}$, and by the ratio of the components mentioned correlate with chrome-spinellids from kimberlites (Sobolev et al., 1975), differing from the latter by lesser $\mathrm{MgO}$ content. The second group is represented by titanium-bearing chrome-spinellids representing a series of solid solutions of chromopicotite-titanomagnetite (Frantsesson et al., 1983). Crome-spinellids of the second group are more ferruginous and highly enriched in $\mathrm{TiO}_{2}$ and depleted in $\mathrm{Cr}_{2} \mathrm{O}_{3}$ and $\mathrm{Al}_{2} \mathrm{O}_{3}$. By $\mathrm{TiO}_{2}$ and $\mathrm{Al}_{2} \mathrm{O}_{3}$ contents they correspond to titanium chrome-bearing magnetites from some dike bodies of lamproites from the Eastern Kimberli (Jakes et al., 1989). 
Garnet is represented by sharp-edged fragments of crystals and angular-rounded corroded grains from $0.2 \mathrm{~mm}$ to $4 \mathrm{~mm}$ in diameter, sometimes with fragments of kelyphitic rims. The garnets studied are depleted in chromium $\left(\mathrm{Cr}_{2} \mathrm{O}_{3}<0.2 \%\right)$ or do not contain cromium admixture at all. Three groups of garnets can be recognized distinguished by chemical composition (Table). The first group includes grains of orange-red, pinkish-red colors consisting (mol.\%) of: almandine (37-56), pyrope (25-47) and grossular (12-21). The second group is formed by bright-red and orange garnets composed of almandine (52-77), pyrope (7-16), grossular (9-22) and spesartine (1-18). The third group is represented by pale-lilac garnets, primarily of almandine composition (76-79) with an admixture of pyrope minal (up to 18\%) and small amounts (less than $3 \%$ ) of grossular and spessartine. The source for the characterized garnets are metamorphic rocks of the Aldan shield basement.

Ingilites represent the product of the mantle magmatism but formed under less deep conditions than kimberlites. This is due to the absence of xenoliths of garnet peridotites and eclogites, chromepyrope and diamond. The presence in ingilites of minerals of various chemical composition (chromeshpinellid, picroilmenite, clinopyroxene) point to complicated conditions of their formation, a probable feature of which is the mixture of various-depth magmatic material.

\section{REFERENCES}

Jakes A., Lewis J., Smith K., 1989, West Australian kimberlites and lamproites. Moscow, MIR Publishing Houses, $430 \mathrm{p}$.

Kaminsky F.V., 1969, Kimberlite-appearing rocks - ingilites. Proceedings of the IV-th All-Union petrographic conference. Baku, p. 258-260.

Romashkin A.I., 1994, Magmatism of Ingiliisk region as indication of Late Proterozoic rifting in the South East of the Siberian platform. Tikhookeanskaya Geologiya, № 5, p. 89-92.

Sobolev N.V., Pokhilenko N.P., Lavrentiev Yu.G., Usova L.V., 1976, Peculiarities of the composition of chrome-spinellids from diamonds and kimberlites of Yakutiya. Geology and Geophysics, № 1, p. 7-24.

Frantsesson Ye.V., Rozova Ye.V., Panteleyev V.V., 1983, Typomorphism of ore minerals of ingilites, related to kimberlites rocks, as a negative feature while searching for diamond-bearing kimberlites. Proceedings of TSNIGRI, v. 178, p. 73-83. 